\title{
KOLOKWIUM HABILITACYJNE DRA JANA MAJCHROWSKIEGO
}

W dniu 21 maja 2012 r. na Wydziale Prawa i Administracji Uniwersytetu Warszawskiego odbyło się kolokwium habilitacyjne dra Jana Majchrowskiego, adiunkta w Katedrze Filozofii Prawa i Nauki o Państwie.

Podstawą przewodu habilitacyjnego była monografia zatytułowana Ewolucja funkcji wojewody jako przedstawiciela Rzqdu. Recenzentami tej rozprawy byli: prof. zw. dr hab. Hubert Izdebski (Uniwersytet Warszawski), prof. zw. dr hab. Mirosław Stec (Uniwersytet Jagielloński), dr hab. prof. UWr Jerzy Supernat (Uniwersytet Wrocławski), prof. zW. dr hab. Wojciech Witkowski (Uniwersytet Marii Curie-Skłodowskiej).

Po przeprowadzeniu kolokwium i wysłuchaniu wykładu habilitacyjnego Rada Wydziału Prawa i Administracji Uniwersytetu Warszawskiego jednogłośnie nadała doktorowi Janowi Majchrowskiemu stopień naukowy doktora habilitowanego nauk prawnych.

ANNA ROSSMANITH (Warszawa)

\section{KOLOKWIUM HABILITACYJNE DRA MARKA KRZYMKOWSKIEGO}

W dniu 19 lutego 2013 r. odbyło się posiedzenie Rady Wydziału Prawa i Administracji Uniwersytetu im. Adama Mickiewicza w Poznaniu, którego przedmiotem było kolokwium habilitacyjne dra Marka Krzymkowskiego, adiunkta w Katedrze Historii Ustroju Państw UAM. Podstawą przewodu habilitacyjnego była rozprawa pod tytułem Rada Stanu Księstwa Warszawskiego (Wydawnictwo Ars boni et aequi, Poznań, ss. 301). Recenzentami pracy habilitacyjnej i dorobku naukowego habilitanta byli: prof. dr hab. Danuta Malec (UJ), prof. dr hab. Marian Kallas (Wyższa Szkoła Finansów i Zarządzania w Warszawie), prof. dr hab. Krzysztof Krasowski (UAM) oraz prof. dr hab. Wojciech Witkowski (UMCS). Habilitant wygłosił wykład habilitacyjny na temat: Prawo urzędnicze II Rzeczypospolitej.

Rada Wydziału Prawa i Administracji UAM postanowiła, w głosowaniu tajnym, nadać doktorowi Markowi Krzymkowskiemu stopień doktora habilitowanego w zakresie historii państwa i prawa. 